\title{
UJI ANALGETIK KOMBINASI EKSTRAK DAUN LIDAH BUAYADAN EKSTRAK JAHE TERHADAP MENCIT YANG DIINDUKSI ASAM ASETAT
}

\author{
Wendi Wijaya ${ }^{1}$, Panta Leon Raynard A.K. ${ }^{2}$, Boyke Marthin Simbolon ${ }^{3}$ \\ ${ }^{1,2}$ Program Studi Pendidikan Dokter, Fakultas Kedokteran, Universitas Prima Indonesia \\ ${ }^{1}$ wendiwijayatantcl@gmail.com
}

\begin{abstract}
Abstrak
Lidah buaya dan jahe merupakan tanaman yang memiliki berbagai macam manfaat dalam bidang Kesehatan, salah satunya digunakan sebagai obat tradisional yang digunakan masyarakat untuk mengobati nyeri. Telah dilakukan penelitian Uji Analgetik Kombinasi Ekstrak Daun Lidah Buaya dan Ekstrak Jahe Terhadap Mencit yang Diinduksi Asam Asetat. Penelitian ini bertujuan untuk mengetahui seberapa baik efek analgetik yang terkandung pada kombinasi ekstrak daun lidah buaya dan ekstrak jahe dalam menurunkan nyeri. Penelitian ini merupakan penelitian eksperimental yang menggunakan 25 ekor mencit yang terdiri dari 5 kelompok sebagai hewan uji coba pada uji analgetik dengan metode induksi kimia yaitu menggunakan asam asetat sebagai zat penginduksi nyeri dan dinilai melalui pengamatan jumlah geliat yang ditunjukkan mencit setelah diintervensi. Pada hasil yang didapatkan, ekstrak lidah buaya dan ekstrak jahe memiliki kandungan senyawa yang bersifat analgetik yaitu alkaloid dengan flavonoid dan memiliki persentase daya analgetik yang lebih dari $50 \%$ serta memiliki efek analgetik yang lebih besar pada dosis $100 \mathrm{mg} / \mathrm{kgBB}$ dibandingkan dengan kontrol positif dari intervensi yang dilakukan yaitu asam mefenamat, dengan perbedaan daya analgetik sebesar 6,64 \%.
\end{abstract}

Kata Kunci : Analgetik, Kombinasi ekstrak daun lidah buaya dan ekstrak jahe, asam asetat, mencit

\begin{abstract}
Aloe vera and ginger are plants that have various benefits in the field of health, one of which is used as a folk remedy used by the public to treat pain. Analgetic Test research has been conducted on the combination of aloe vera leaf extract and ginger extract against acetic acid-induced mice. This study aims to find out how well the analgesic effects contained on the combination of aloe vera leaf extract and ginger extract in lowering pain. This study was an experimental study that used 25 mencit consisting of 5 groups as a test animal in analgesic trials with a method of chemical induction that is to use acetic acid as a pain-inducing substance and assessed through observation of the number of ticks shown to be squeaky after intervening. In the results obtained, aloe vera extract and ginger extract have an analgetic compound content that is alkaloid with flavonoids and has a percentage of analgesic power that is more than $50 \%$ and has a greater analgesic effect at a dose of $100 \mathrm{mg} /$ kgBB compared to positive control of the interventions carried out namely mefenamat acid, with an analgesic power difference of $6.64 \%$.
\end{abstract}

Keywords: Analgesic, combination of aloe vera leaf extract and ginger extract, acetic acid, mice 


\section{PENDAHULUAN}

Nyeri atau yang dikenal sebagai rasa sakit merupakan pengalaman sensorik dan emosional yang tidak menyenangkan yang disebakan karena adanya stimulus akibat dari rusaknya suatu jaringan baik di bagian luar permukaan kulit maupun bagian dalam organ ataupun akibat dari suatu mediator kimiawi. Proses nyeri disebabkan karena adanya proses yang banyak mulai dari nosisepsi, sensitasi perifer, perubahan fenotip, sensitasi sentral, penurunan inhibisi dan reorganisasi nyeri ${ }^{(1-3)}$.

Nyeri dapat dirasakan berdasarkan intensitas (mulai dari ringan, sedang hingga berat), kualitas (nyeri tumpul, nyeri tajam), durasi (akut dan kronis), dan penyebarannya ( superfisial atau dalam, terlokalisir atau difus) serta lokasinya ( nyeri somatik dan nyeri visceral). Nyeri dirasakan seperti sesuatu hal yang disebut sensasi, akan tetapi nyeri memiliki komponen didalamnya yaitu kognitif dan emosional. Berdasarkan jalur patofisologinya, nyeri dapat dibagi menjadi nyeri nosiseptif, nyeri neurologi, nyeri psikologi dan nyeri idiopatik. Fisiologi nyeri sendiri terjadi akibat dari banyak faktor dan akibatnya terjadi proses terjadinya nyeri yaitu transduksi, transmisi, modulasi dan persepsi. Jika nyeri tidak segera ditangani, maka nyeri yang dialami akan mengganggu aktivitas sehari hari dan akan bertambah buruk, baik dari keadaan fisik maupun keadaan psikologis dari penderita nyeri jika tidak segera ditangani dengan tepat ${ }^{(2,4)}$.

Pada kesehariannya, nyeri dapat ditangani secara farmakologis dan non farmakologis. dalam kedokteran atau farmakologi, terapi farmakologi diberikan obat sintetik yang memiliki efek analgetik, yang terbagi menjadi gologan non narkotika dengan golongan narkotika yang biasa diresepkan oleh dokter tergantung dari intensitas nyeri yang dirasakan. Analgetik narkotik digunakan pada saat pasien merasakan nyeri yang benar benar megganggu atau dengan intesitas sedang hingga berat. Sedangkan obat analgetik golongan non narkotika atau perifer sering dipakai secara umum oleh masyarakat dalam sehari harinya untuk mengatasi nyeri seperti obat golongan acetaminophen, salisilat, NSAID, derivat-antranilat, dan derivat-pirazolinon. Salah satu obat yang sering digunakan yaitu obat golongan NSAID seperti asam mefenamat yang sehari harinya digunakan sebagai obat untuk meredakan nyeri, seperti sakit gigi, nyeri kepala dan haid ${ }^{(5-7)}$

Pada kesehariannya, masyarakat mengatasi nyeri dengan cara terapi farmakologi. Akan tetapi ada juga yang menggunakan terapi tanpa menggunakan obat sintetik atau non farmakologi yaitu dimulai dari terapi fisik, kognitif dan lainnya. Akan tetapi, ada beberapa masyarakat di Indonesia menggunakan obat tradisional sebagai pilihan utama dalam mengatasi nyeri yang disebabkan karena Indonesia memiliki berbagai macam obat tradisional yang bisa didapat atau dimanfaatkan secara langsung dari alam, seperti tanaman yang sering digunakan sebagai obat tradisional yaitu lidah buaya dan jahe. Lidah buaya dan Jahe banyak digunakan sebagai obat tradisional karena selain banyak dijumpai di Indonesia, lidah buaya dan jahe sangat mudah didapatkan di berbagai daerah di Indonesia, serta dipercaya memiliki segudang manfaat dalam dunia kesehatan, salah satunya sebagai analgetik alami. Lidah buaya yang memiliki nama latin Aloe vera ini memiliki berbagai kandungan seyawa aktif didalamnya sebagai analgetik alami, salah satunya antrakuinon dan kuinon dengan mencegah terbentuknya prostaglandin yang dapat merangsang terjadinya nyeri dan jahe dapat digunakan sebagai antioksidan, anti inflamasi, antikarsinogenik, dan terutama memiliki fungsi analgetik karna memiliki kandungan seperti flavonoid, gingerol, zingeron, shogaol, arginin. Gingerol berfungsi sebagai penghambat sintesis prostaglandin yang menyebabkan jahe memiliki fungsi analgetik dan dipercaya juga karena dipercaya dapat mengobati berbagai macam penyakit seperti impoten, batuk, radang sendi, kepala pusing, rematik, masuk angin, bronkitis, nyeri lambung, nyeri otot, vertigo, kanker dan lainnya ${ }^{(8-11)}$.

Penelitian yang dilakukan oleh Muqsith (2017) yaitu uji daya analgetik jus daun lidah buaya menyatakan lidah buaya dengan dosis tertentu memilki efek analgetik dan pada dosis yang tinggi memiliki efek antiseptik yang lebih dominan dibandingkan dengan efek analgetik yang diberikan pada mencit yang diinduksi asam asetat.

Penelitian yang dilakukan Dewi dan Hiany Salim (2018) yaitu uji efek analgetik menggunakan infusa jahe pada mencit menyatakan jahe memiliki efek analgetik terhadap penurunan nyeri yang dilakukan pada mencit yang diinduksi asam asetat.

Berdasarkan dari penjelasan yang ada diatas, peneliti ingin mengetahui efektivitas analgetik jika kedua tanaman alami diatas yaitu lidah buaya dan jahe dikombinasi akan meningkat atau tidak dengan membandingkannya dengan obat sintetik yaitu asam mefenamat dengan konsentrasi dari ekstrak lidah buaya sebesar $75 \%$ yang dikombinasikan dengan ekstrak jahe dengan konsentrasi $75 \%$ yang akan diberikan ke mencit yang mengalami nyeri 
akibat induksi asam asetat dalam bentuk sediaan oral.

\section{METODE}

Penelitian ini menggunakan desain penelitian eksperimental rancangan Post Test Only Control Group Design karena hewan uji yaitu mencit melakukan perbandingan antar kelompok yang dilakukan secara langsung tanpa perlakuan khusus.

Penelitian ini dilakukan di Laboratorium Farmakologi dan Toksikologi Fakultas Farmasi Universitas Sumatera Utara sebagai tempat untuk menguji efek analgetik pada mencit yang diinduksi asam asetat $1 \%$ serta pembuatan kombinasi ekstrak daun lidah buaya dan ekstrak jahe, Laboratorium Hewan Coba (Animal House) FMIPA Biologi Universitas Sumatera Utara untuk tempat mencit beradaptasi dengan lingkungan lab dan Laboratorium Biologi Farmasi Universitas Sumatera Utara yaitu tempat untuk melakukan skrining fitokimia yang dilakukan pada bulan Juli 2020 sampai bulan September 2020.

Sampel penelitian ini menggunakan ekstrak daun lidah buaya dan ekstrak jahe yang dikombinasikan menjadi satu ekstrak. Sampel hewan uji coba yang akan diintervensi pada penelitian ini yaitu mencit. Besar sampel dihitung berdasarkan rumus Federer, yaitu :

$(\mathrm{T}-1)(\mathrm{N}-1) \geq 15$

Keterangan :

$\mathrm{T}=$ Jumlah Perlakuan

$\mathrm{N}$ = Jumlah Sampel

Dalam penelitian yang akan dilakukan, terbagi atas 5 kelompok sehingga jumlah sampel yang dibutuhkan yaitu

$(5-1)(N-1) \geq 15$

(4) $(\mathrm{N}-1) \geq 15$

$\mathrm{N}-1 \geq 15 / 4$

$\mathrm{N}-1 \geq 3,75$

$N \geq 3,75+1=4,75=5$ (12).

Berdasarkan rumus tersebut, pada penelitian ini sampel yang digunakan di setiap 1 kelompok adalah 5 ekor mencit, dengan jumlah keseluruhan sampel yang digunakan adalah sebanyak 25 ekor mencit.

Data dari kombinasi ekstrak daun daun lidah buaya (Aloe vera) dan ekstrak jahe (Zingiber Officinale) yang diambil selama penelitian berlangsung di laboratorium merupakan data primer dalam pengujian efek analgetik terhadap mencit yang diinduksi asam asetat.

Instrumen Penelitian

Bejana maserasi, timbangan analitik, stopwatch, alat-alat gelas, sonde oral, batang pengaduk, kertas saring, kertas perkamen, aluminium foil, tabung reaksi, kapas, rotary evaporator, kapas alkohol, autoclave, blender, lumpang, alu, lemari pengering, oven, disposyble syringe $1 \mathrm{ml}$, spuit $1 \mathrm{ml}$, kandang pemeliharaan hewan, tempat makan dan air minum hewan peliharaan, catatan, alat ukur (Visual Analog scale) Skala Meringis), sarung tangan, masker.

\section{Metode Ekstraksi}

Sebelum ekstrak dikombinasi, ekstrak daun lidah buaya dan ekstrak jahe pada penelitian ini menggunakan metode maserasi. Pertama- tama siapkan alat dan bahan yang akan digunakan mulai mengekstrak lidah buaya dan jahe. Sampel lidah buaya dan jahe yang sudah dibersihkan di air yang mengalir diambil bagian yang ingin di ekstrak yaitu daun dari lidah buaya dipisahkan dari daging dan gelnya. Sedangkan jahe diambil rimpangnya. Kemudian menimbang kedua sampel yang telah dipisahkan. Sampel daun lidah buaya ditimbang sebanyak $14 \mathrm{~kg}$ dan jahe sebanyak $5 \mathrm{~kg}$. Kemudian kedua sampel dipisah dan dipotong kecil-kecil untuk mempermudah proses pengeringan nantinya. Proses pengeringan kedua sampel dilakukan di lemari pengering selama kurang lebih 1 jam. Sampel yang sudah kering kemudian dihaluskan dengan cara diblender hingga menjadi serbuk dan kemudian ditimbang. Serbuk yang dihasilkan diayak dengan ayakan, hingga diperoleh serbuk yang halus, yaitu sekitar 300 gram serbuk daun lidah buaya dan 500 gram untuk serbuk jahe. Kedua ekstrak akan dikombinasikan dengan cara dimasukkan ke wadah gelas dan diaduk sampai merata. Setelah tercampur rata, tambahkan pelarut etanol $96 \%$ sebanyak 8000 $\mathrm{ml}$ dengan perbandingan $1: 8$, lalu ditutup dan dibiarkan selama 5 hari dari cahaya (setiap sampel diaduk). Setelah 5 hari proses maserasi (perendaman sampel) dilakukan, rendaman disaring dengan menggunakan kertas saring sehingga menghasilkan filtrat dan debris. Kemudian dilanjutkan dengan proses remaserasi dengan ekstrak etanol 96\% sebanyak $2000 \mathrm{ml}$ selama 2 hari. Filtrat hasil maserasi dan remaserasi digabung kemudian dimasukkan ke dalam oven pada suhu $40^{\circ} \mathrm{C}$ dengan tujuan pemekatan ekstrak sampai ekstrak kental. Konsentrasi ekstrak daun lidah buaya dan ekstrak jahe didapatkan konsentrasi sebesar $75 \%{ }^{(12)}$.

\section{Penentuan Dosis Pada Uji Efek Analgetik}

Pada Penelitian uji efek analgetik pada mencit ini menggunakan :

1. Asam asetat $1 \%$ sebagai induksi nyeri diberikan pada mencit dengan dosis sebesar $40 \mathrm{mg} / \mathrm{kgBB}$

2. Asam mefenamat dengan dosis $65 \mathrm{mg} / \mathrm{kgBB}$ 
3. Kombinasi ekstrak daun lidah buaya dan ekstrak jahe dengan dosis sebesar $50 \mathrm{mg} / \mathrm{kgBB}$

4. Kombinasi ekstrak daun lidah buaya dan ekstrak jahe dengan dosis sebesar $100 \mathrm{mg} / \mathrm{kgBB}$

\section{Perlakuan Hewan Uji Coba}

Penelitian ini mengunakan hewan coba mencit dengan berat sekitar 20 - 40 gram. Sebelum percobaan dimulai, mencit akan dirawat dengan pemberian makan serta minum secara rutin agar dalam kondisi yang sehat dan dibiarkan beradaptasi di suasana ruangan penelitian selama kurang lebih 1 minggu. Pembagian hewan coba terdiri dari 5 kelompok dan semuanya berjumlah 20 ekor mencit, dimana setiap kelompok terdiri dari 4 ekor mencit. Perlakuan yang akan diberikan disetiap kelompok adalah sebagai berikut :

Kelompok I P (-) : Hanya diinduksi asam asetat $1 \%$ Kelompok II P(+) : Diinduksi asam asetat lalu diberikan asam mefenamat dengan dosis $10 \mathrm{mg} / \mathrm{kg}$ BB

Kelompok III P1 : Diinduksi asam asetat $1 \%$ lalu diberikan larutan CMC 2\%

Kelompok IV P2 : Diinduksi asam asetat lalu diberikan sediaan oral ekstrak yang sudah dikombinasi dengan dosis $50 \mathrm{mg} / \mathrm{kg} \mathrm{BB}$

Kelompok V P3 : Diinduksi asam asetat lalu diberikan sedian oral ekstrak yang sudah dikombinasi dengan dosis $100 \mathrm{mg} / \mathrm{kg} \mathrm{BB}$

\section{Analisis data}

Data dari hasil penelitian ini dianalisis menggunakan program SPSS versi 25 . Semua data yang dikumpulkan dari semua kelompok kontrol dan kelompok perlakuan terhadap uji efek analgetik pada mencit dilakukan uji normalitas (uji Kolmogorov-Smirnov). Apabila data terdistribusi normal yaitu nilai $\mathrm{P}>0,05$ akan dilanjutkan dengan uji analisis One Way ANNOVA untuk mengetahui apakah ada pengaruh efek analgetik pemberian ekstrak kombinasi daun lidah buaya dan jahe pada variasi dosis terhadap mencit yang mengalami nyeri akibat induksi asam asetat. Jika uji analisis varian berbeda dengan nilai $\mathrm{P}<0,05$, akan menggunakan uji analisis Kruskal-Wall.

\section{HASIL DAN PEMBAHASAN}

Hasil yang didapatkan dari penelitian ini berupa :

Hasil Skrining Fitokimia

Hasil uji skrining fitokimia menunjukkan jahe mengandung senyawa alkaloid, flavonoid, glikosida, saponin, tanin, dan Triterpenoid/Steroid. Kandungan alkaloid $(+)$, flavonoid $(+)$, glikosida $(+)$ dan triterpenoid/steroid $(+)$ termasuk lebih tinggi $(+)$ dibandingkan dengan saponin (-) dan tanin (-). Sementara penapisan fitokimia menunjukkan lidah buaya kandungan flavonoid (+), glikosida (+), saponin $(+)$ dan tanin $(+)$ dan triterpenoid/steroid $(+)$ termasuk lebih tinggi $(+)$ dibandingkan dengan alkaloid (-). Berikut ini hasil Uji Skrining Fitokimia sebagai tabel berikut :

Tabel 1 Hasil Skrining Fitokimia dari ekstrak daun lidah buaya dan ekstrak jahe

\begin{tabular}{|c|c|c|c|c|}
\hline No & Metabolit Sekunder & Jahe & $\begin{array}{l}\text { lidah } \\
\text { Buaya }\end{array}$ & Pereaksi \\
\hline 1 & Alkaloid & + & - & $\begin{array}{l}\text { Dragendroff } \\
\text { Bouchardat } \\
\text { Meyer }\end{array}$ \\
\hline 2 & Flavonoid & + & + & $\begin{array}{l}\text { Serbuk Mg + } \\
\text { Amil Alkohol + } \\
\text { HClp }\end{array}$ \\
\hline 3 & Glikosida & + & + & $\begin{array}{ll}\text { Molish } & + \\
\mathrm{H} 2 \mathrm{SO} 4 & \\
\end{array}$ \\
\hline 4 & Saponin & - & + & $\begin{array}{l}\text { Air } \\
\text { panas/dikocok }\end{array}$ \\
\hline 5 & Tanin & - & + & $\mathrm{FeCl} 3$ \\
\hline 6 & Triterpenoid/Steroid & + & + & $\begin{array}{l}\text { Lieberman- } \\
\text { Bourchat }\end{array}$ \\
\hline
\end{tabular}

Efek Analgetik Pada Metode Induksi Kimia

Berikut ini rata - rata dan standar deviasi hasil percobaan Refleks Geliat yang Ditunjukkan oleh si Mencit dalam 5 perlakuan yang dikelompokkan kedalam 5 kelompok yang sudah dijelaskan sebelumnya dan dijabarkan pada tabel 2 
Jurnal Ilmiah Mahasiswa Kesehatan Masyarakat Vol. 5/No.4/Oktober 2020; ISSN:2502-731X

Tabel 2 Rata - rata Jumlah Refleks Geliat di Setiap kelompok

\begin{tabular}{|c|c|c|}
\hline Kelompok & Perlakuan & Rata-rata \pm SD jumlah geliat \\
\hline $\begin{array}{l}\text { Kelompok I } \\
\text { Kelompok II }\end{array}$ & $\begin{array}{l}\text { Induksi asam asetat } 1 \% \\
\text { Induksi asam asetat } 1 \% \text { dengan diberikan } \\
\text { larutan CMC } 2 \%\end{array}$ & $\begin{array}{l}128,58 \pm 28,43 \\
114,75 \pm 26,98\end{array}$ \\
\hline Kelompok III & $\begin{array}{l}\text { Induksi asam asetat } 1 \% \text { dengan diberikan } \\
\text { Asam Mefenamat dengan dosis } 65 \mathrm{mg} / \mathrm{kg} / \mathrm{BB}\end{array}$ & $34,33 \pm 17,34$ \\
\hline Kelompok IV & $\begin{array}{l}\text { Induksi asam asetat } 1 \% \text { dengan diberikann } \\
\text { Ekstrak kombinasi dengan dosis } 50 \mathrm{mg} / \mathrm{kgBB}\end{array}$ & $51,00 \pm 24,29$ \\
\hline Kelompok V & $\begin{array}{l}\text { Induksi asam asetat } 1 \% \text { dengan diberikan } \\
\text { ekstrak kombinasi dengan dosis } 100 \mathrm{mg} / \mathrm{kgBB}\end{array}$ & $25,75 \pm 19,49$ \\
\hline
\end{tabular}

Kemudian setiap kelompok dalam perlakuan tersebut diuji pada rentang waktu percobaan sebanyak 12 waktu pengamatan. Dimana pengamatan pertama selama 5 menit, 10 menit, 15 menit, 20 menit, 25 menit, 30 menit, 35 menit, 40 menit, 45 menit, 50 menit, 55 menit dan sampai dengan 60 menit. Selama pengamatan tersebut diperoleh hasil bahwa nilai Refleks Geliat yang ditunjukkan oleh si Mencit semakin lama semakin menurun untuk setiap perlakuan. Hal ini menunjukkan bahwa penurunan nyeri atau efek analgetik pada mencit (Mus musculus) yang diinduksi asam asetat dipengaruhi oleh waktu pengamatan dimana semakin lama akan semakin berkurang nyeri atau efek analgetik (dijabarkan di Tabel 3)

Tabel 3 Rata-rata dan Standar Deviasi per waktu Pengamatan.

\begin{tabular}{lllllllllllll}
\hline $\begin{array}{l}\text { Kelo } \\
\text { mpok }\end{array}$ & $\mathbf{5}$ & $\mathbf{1 0}$ & $\mathbf{1 5}$ & $\mathbf{2 0}$ & $\mathbf{2 5}$ & $\mathbf{3 0}$ & $\mathbf{3 5}$ & $\mathbf{4 0}$ & $\mathbf{4 5}$ & $\mathbf{5 0}$ & $\mathbf{5 5}$ & $\mathbf{6 0}$ \\
\hline I & & & & & & & & & & & & \\
\hline II & $33,2 \pm 2,5$ & $32,8 \pm 2,6$ & $31 \pm 3,0$ & $29,8 \pm 3,0$ & $28,6 \pm 2,0$ & $27 \pm 2,1$ & $24,8 \pm 2,0$ & $24 \pm 2,1$ & $22,4 \pm 2,3$ & $20,2 \pm 2,5$ & $18,6 \pm 1,9$ & $16,2 \pm 1,9$ \\
\hline III & $16,6 \pm 1,9$ & $29,6 \pm 1,8$ & $28,4 \pm 1,3$ & $27,4 \pm 2,3$ & $25,6 \pm 2,8$ & $24,2 \pm 2,8$ & $22,2 \pm 2,2$ & $21,2 \pm 2,4$ & $19,2 \pm 2,5$ & $17,4 \pm 2,6$ & $16,2 \pm 2,3$ & $13,4 \pm 2,1$ \\
\hline IV & $22,4 \pm 3,2$ & $19 \pm 2,0$ & $17,2 \pm 2,2$ & $14,6 \pm 2,3$ & $12 \pm 2,0$ & $10,2 \pm 2,9$ & $8,6 \pm 2,1$ & $6,8 \pm 2,4$ & $4,8 \pm 1,9$ & $3,4 \pm 1,5$ & $2,4 \pm 1,1$ & $1 \pm 0,7$ \\
\hline V & $14,4 \pm 3,9$ & $12,4 \pm 3,9$ & $11 \pm 2,7$ & $8,2 \pm 2,4$ & $6,6 \pm 2,1$ & $4 \pm 1,6$ & $2,6 \pm 1,3$ & $1,4 \pm 0,5$ & $0,8 \pm 0,4$ & $0,4 \pm 0,5$ & $0 \pm 0$ & $0 \pm 0$ \\
\hline
\end{tabular}

Berikut ini grafik rata-rata hasil Refleks Geliat yang Ditunjukkan oleh si Mencit berdasarkan kelompok perlakuannya dan waktu pengamatannya.

Gambar 1 Nilai Refleks Geliat di setiap 5 menit selama 60 menit

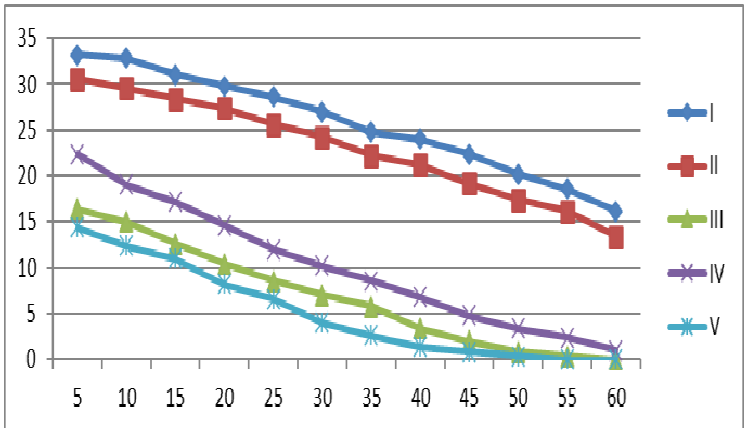

Dari hasil grafik yang ditunjukkan pada gambar 1 dapat dilihat nilai refleks geliat yang ditunjukkan oleh si mencit semakin lama semakin menurun untuk setiap perlakuan seiring dengan berjalannya waktu.

\section{Hasil Akhir Uji Efek Analgetik}

Data penelitian diambil bedasarkan nilai kumulatif pada jumlah refleks geliat yang ditunjukkan mencit disetiap kelompoknya. Untuk melihat daya analgetik bekerja atau tidak, dapat di ukur dengan menggunkan persamaan rumus dari Handersot dan Forsaith yaitu:

\% Daya Analgetik yang timbul dari refleks geliat = $100-(\mathrm{P} / \mathrm{K} \times 100)$

Keterangan

$\mathrm{P}=$ Jumlah Kumulatif refleks geliat yang timbul setelah diberi perlakuan

$\mathrm{K}=$ Jumlah rata-rata refleks geliat hewan uji coba pada kontrol

Yang berikut dijelaskan pada Tabel 3 
Tabel 4 \% Daya Analgetik ke 5 kelompok mencit setelah dirata-rata kan

\begin{tabular}{lll}
\hline Kelompok & $\begin{array}{l}\text { Rata-rata } \pm \text { SD jumlah } \\
\text { geliat }\end{array}$ & $\begin{array}{l}\% \text { Daya } \\
\text { Analgetik }\end{array}$ \\
\hline Kelompok I & $128,58 \pm 28,43$ & 0 \\
\hline Kelompok II & $114,75 \pm 26,98$ & 10,76 \\
\hline Kelompok III & $34,33 \pm 17,34$ & 73,30 \\
\hline Kelompok IV & $51,00 \pm 24,29$ & 60,34 \\
\hline Kelompok V & $25,75 \pm 19,49$ & 79,97 \\
\hline
\end{tabular}

Dari tabel diatas menunjukkan bahwa pada perlakuan kelompok IV yang menggunakan induksi asam asetat $1 \%$ dengan diberikann Ekstrak kombinasi dengan dosis memiliki potensi analgetik yang paling baik $(79,97 \%)$ dibandingkan dengan perlakuan kontrol atau kelompok I yang hanya menggunakan induksi asam asetat $1 \%$ dan perlakuan kelompok lainnya.

Sedangkan untuk persentase efektivitas analgetik yaitu kemampuan bahan uji dalam mengurangi respon pada mencit yang disebabkan oleh induksi. Pengolahan data dihitung dengan rumus sebagai berikut:

\%EfektivitasAnalgetik=

Bata-rata daya analigetik kelompok perlakukan

Bata- rata daya analgetik kelompok Astagol $\times 100 \%$ )

Tabel $5 \%$ Efektivitas Analgetik

\begin{tabular}{lllll}
\hline Kelompok & $\begin{array}{l}\text { Rata-rata } \pm \\
\text { SD jumlah } \\
\text { geliat }\end{array}$ & $\begin{array}{l}\text { Daya } \\
\text { Analgetik }\end{array}$ & $\begin{array}{l}\% \\
\text { Efektivitas } \\
\text { Analgetik }\end{array}$ \\
\hline Kelompok I & $\begin{array}{l}128,58 \\
28,43\end{array}$ & \pm & 0 & \\
\hline $\begin{array}{l}\text { Kelompok } \\
\text { II }\end{array}$ & $\begin{array}{l}114,75 \\
26,98\end{array}$ & \pm & 10,76 & 100,00 \\
\hline Kelompok & 34,33 & \pm & 73,30 & \\
III & 17,34 & & 681,33 \\
\hline Kelompok & 51,00 & \pm & 60,34 & \\
IV & 24,29 & & 560,84 \\
\hline Kelompok & 25,75 & \pm & 79,97 & 743,37 \\
V & 19,49 & & &
\end{tabular}

\section{Uji Persyarat Data}

Pengolahan data pada uji prasyarat menggunakan uji Normalitas dan Homogenitas

Uji Normalitas

Uji normalitas yang digunakan pada penelitian ini menggunakan uji Shapiro -Wilk. Metode shapiro wilk adalah metode uji normalitas yang efektif dan valid digunakan untuk sampel berjumlah kecil.

- Ho : Data berdistribusi normal

-H1 : Data tidak berdistribusi normal

Ketentuan

Jika nilai $\mathrm{p}>5 \%$. maka Ho diterima : $\mathrm{H} 1$ ditolak

Jika nilai $p<5 \%$. maka Ho ditolak : H1 diterima
Dari hasil SPSS tersebut semua data berdistribusi normal atau nilai Asymp sig lebih besar dari 0,05. Dapat dilihat pada tabel 5.

Tabel 6 One-Sample Kolmogorov-Smirnov Test yang Terdistribusi Normal

\begin{tabular}{|c|c|c|c|c|c|}
\hline & I & II & III & IV & V \\
\hline $\mathrm{N}$ & 12 & 12 & 12 & 12 & 12 \\
\hline \multirow[t]{2}{*}{$\begin{array}{l}\text { Normal } \\
\text { Parameter } \\
\mathrm{s}^{\mathrm{a}}\end{array}$} & Mean & $\begin{array}{l}25.716 \\
7\end{array}$ & $\begin{array}{l}22.950 \\
0\end{array}$ & 6.8667 & $\begin{array}{l}10.200 \\
0\end{array}$ \\
\hline & $\begin{array}{l}\text { Std. } \\
\text { Deviatio } \\
\mathrm{n}\end{array}$ & $\begin{array}{l}5.6178 \\
0\end{array}$ & $\begin{array}{l}5.6091 \\
6\end{array}$ & $\begin{array}{l}5.7842 \\
0\end{array}$ & $\begin{array}{l}6.9601 \\
5\end{array}$ \\
\hline \multirow{3}{*}{$\begin{array}{l}\text { Most } \\
\text { Extreme } \\
\text { Differences }\end{array}$} & $\begin{array}{l}\text { Absolut } \\
\mathrm{e}\end{array}$ & .113 & .120 & .142 & .114 \\
\hline & Positive & .091 & .089 & .142 & .114 \\
\hline & $\begin{array}{l}\text { Negativ } \\
\mathrm{e}\end{array}$ & -.113 & -.120 & -.118 & -.093 \\
\hline $\begin{array}{l}\text { Kolmogoro } \\
\text { v-Smirnov } \\
\text { Z }\end{array}$ & .391 & .414 & .493 & .396 & .649 \\
\hline
\end{tabular}

\section{Uji Homogenitas}

Uji Levene digunakan untuk menguji kesamaan varians dari beberapa populasi.

- Ho : Semua variansi sama atau homogen

-H1 : Semua vairiansi tidak sama atau tidak homogen

Ketentuan

Jika nilai $\mathrm{p}>5 \%$. maka Ho diterima ; $\mathrm{H} 1$ ditolak Jika nilai $p<5 \%$. maka Ho ditolak; H1 diterima.

Tabel 7 Hasil Homogenitas Data Pretest dari varian homegenitas

\begin{tabular}{cccc}
\hline Levene Statistic & df1 & df2 & Sig. \\
\hline .329 & 4 & 55 & .857 \\
\hline \multicolumn{4}{r}{ Diperoleh nilai } \\
\hline
\end{tabular}
dari 0.857 atau lebih besar dari 0.05 sehingga dapat disimpulakan bahwa Ho diterima atau data homogen.

Pengolahan data pada uji prasyarat pada data kontrol dan data perlakuan terhadap efek analgetik pada mencit semuanya menunjukkan hasil nilai Asymp sig lebih besar dari 0,05 atau data berdistribusi Normal dan uji homogenitas memiliki nilai signifikansi uji Levene sebesar dari 0.857 atau lebih besar dari 0.05 sehingga dapat disimpulkan bahwa Ho diterima atau data homogen. Dengan melihat hasil tersebut maka uii lanjutan pada penelitian ini menggunakan uji parametrik yaitu uji Anova. 
Tabel 8 Hasil Statistik Anova

\begin{tabular}{llllll}
\hline Data & $\begin{array}{l}\text { Sum of } \\
\text { Squares }\end{array}$ & Df & $\begin{array}{l}\text { Sean } \\
\text { Square }\end{array}$ & F & Sig. \\
\hline $\begin{array}{l}\text { Between } \\
\text { Groups }\end{array}$ & 4330.484 & 4 & 1082.621 & 31.433 & .000 \\
\hline $\begin{array}{l}\text { Within } \\
\text { Groups }\end{array}$ & 1894.323 & 55 & 34.442 & & \\
\hline Total & 6224.807 & 59 & & & \\
\hline
\end{tabular}

Nilai tersebut yang diperoleh kemudian dianalisis secara statistik one way ANOVA dengan metode Bonfferoni dan nilai signifikansi $\mathrm{P}<0,05$. Dari hasil uji Anova diperoleh nilai sig 0,000 atau lebih kecil dari 0,05 , sehingga menunjukkan adanya pengaruh perlakuan terhadap percobaan tersebut. Secara keseluruhan perlakuan yang di berikan dalam percobaan tersebut memilki perbedaan artinya perlakuan yang berikan memberikan pengaruh terhadap penurunan nyeri atau efek analgetik pada mencit (Mus musculus).

\section{PEMBAHASAN}

Nyeri adalah pengalaman sensoris serta emosional yang diakibatkan adanya kerusakkan jaringan yang bersifat aktual dan potensial sehingga timbullah reseptor nyeri yang ada di jaringan yang rusak sehingga merangsangnya untuk melepaskan mediator inflamasi. Untuk menangani nyeri yang dialami, dibutuhkan penanganan khusus dalam nyeri yaitu dengan pemberian obat atau pun zat yang dapat menurunkan nyeri yaitu zat yang memiliki efek analgetik ${ }^{(9,13)}$.

Dari hasil yang didapatkan, menunjukkan bahwa efek analgetik kombinasi antara ekstrak jahe dan ekstrak daun lidah buaya menunjukkan efek analgetik > 50\% dimana pada dosis $100 \mathrm{mg} / \mathrm{kgBB}$ memiliki efek analgetik yang lebih tinggi dibandingkan dengan kontrol positif yang dipakai yaitu asam mefenamat dengan dosis $65 \mathrm{mg} / \mathrm{kgBB}$ dengan intervensi pada mencit yang diinduksi asam asetat dan melihat refleks geliat yang ditunjukkannya setiap 5 menit sekali selama 60 menit yaitu sebesar 79,99\% untuk daya analgetik.

Menurut penelitian yang dilakukan oleh Muqsith (2017) dengan metode yang sama namun hanya menggunakan ektrak lidah buaya sebagai pembanding analgetic dengan paracetamol. Hasil yang ditunjukkan dari penelitian ini adalah pemberian ekstrak daun lidah buaya dengan dosis $400 \mathrm{mg} / \mathrm{kgBB}$ menunjukkan hasil yang signifikan dibandingkan dosis $800 \mathrm{mg} / \mathrm{kgBB}$ yaitu dengan perbandingan persentase efek analgetik $85,71 \%$ dan $76,41 \%$. Dan didapatkan pula dari hasil skirining fitokimia yang terkandung didalam gel lidah buaya terdapat lignin, saponin, enzim dan kompleks antrakuinon yang memiliki turunan aloin, barbaloin, iso-barbaloin, anthranol, aloe emodin, anthracene, aloetic acid, ester asam sinamat, asam krisophanat, ester oil, resistanol. Maka dapat dismpulkan dari penelitian yang dilakukan oleh A musqit bahwa lidah buaya dengan dosis tinggi efek analgetiknya akan lebih rendah efeknya dibandingkan dengan efek antibakterinya ${ }^{(9)}$.

Pada penelitian yang dilakukan oleh Febriani et al.(2018) menggunakan ekstrak air jahe merah dan ekstrak etanol ampas jah merah sebagai intervensi terhadap mencit yang diinduksi asam asetat dan menggunakan asetosal sebagai kontrol positifnya. Pada penelitian ini, waktu intervensi untuk melihat refleks geliat dari mencit dilakukan selama 30 menit. Pada hasil penelitian didapatkan ektrak air jahe merah dan ekstrak etanol ampas jahe merah memiliki efek analgetik terhadap penurunan refleks geliat pada mencit. Namun, efek analgetik pada ektrak air jahe merah diketahui memiliki efektivitas penurunan nyeri selama 25 menit dan ekstrak etanol ampas jahe merah memiliki efektivitas sampai dengan 30 menit ${ }^{(13)}$.

Pada peneltian yang dilakukan Dewi dan Hiany Salim (2018) memilih ekstrak jahe sebagai intervensinya dan asam mefenamat sebagai kontrolnya. Hasil yang didapatkan terdapat perbedaan efektivitas penurunan nyeri di setiap kelompok yang diintervensi selama 60 menit dengan konsentrasi yang berbeda. Infusa jahe $10 \%$, $20 \%, 30 \%$ memilik efek analgetik terhadap mencit dan pada konsentrasi $10 \%$ memiliki efek analgetik yang paling rendah. Pada penelitian ini dibuktikan semakin rendah konsentrasi infusa jahe maka semakin rendah efek analgetik yang ditimbulkan.

Pada penelitian ini didapatkan hasil dari ekstrak jahe dan daun lidah buaya terbukti memiliki efek analgetik secara farmakologis, karena memiliki kandungan efek analgetik. kandungan yang terdapat pada jahe putih adalah Alkaloid, Flavonoid, Glikosida, serta Triterpen/Steroid. Sedangkan pada ekstrak daun lidah buaya terdapat Flavonoid, Glikosida, Saponin, Tanin, dan Triterpen/Steroid. Kombinasi antara ekstrak jahe putih dan ekstrak daun lidah buaya memiliki kandungan Alkaloid dan Flavonoid. Menurut penelitian (Kaunang, Bodhi and Edy, 2020) bahwasanya kandungan alkaloid memiliki fungsi mengurangi rasa nyeri dengan menghambat sintesis dan pelepasan leukotrin. Sedangkan Flavonoid bekerja menghambat enzim siklooksigenase. Oleh karena itu produksi prostaglandin oleh asam arakidonat akan menurun sehingga akan menimbulkan efek analgetik ${ }^{(15)}$. 


\section{SIMPULAN}

1. Terdapat berbagai macam senyawa yang memiliki efek analgetik yang terdapat pada kombinasi ekstrak daun lidah buaya dan ekstrak jahe terhadap mencit yang diinduksi asam asetat.

2. Pada penelitian ini, seiring dengan berjalannya waktu terdapat penurunan jumlah refleks geliat pada mencit yang diinduksi asam asetat tetapi berbeda di setiap kelompok perlakuan.

3. Kombinasi ekstrak daun lidah buaya dan ekstrak jahe memilik efek analgetik terhadap penurunan jumlah refleks geliat pada mencit yang diinduksi asam asetat

4. Kombinasi ekstrak daun lidah buaya dan ekstrak jahe memiliki efek analgetik $>50 \%$ yaitu dengan dosis $50 \mathrm{mg} / \mathrm{kgBB}$ dan $100 \mathrm{mg} / \mathrm{kgBB}$ yaitu sebesar $60,34 \%$ untuk dosis $50 \mathrm{mg} / \mathrm{kgBB}$ dan 79,97\% untuk dosis $100 \mathrm{mg} / \mathrm{kgBB}$.

5. Pada kelompok kontrol positif yaitu asam mefenamat memiliki efek analgetik yang lebih kecil dibandingkan dengan kelompok intervensi dengan pemberian kombinasi ekstrak daun lidah buaya dan ekstrak jahe dengan dosis 100 $\mathrm{mg} / \mathrm{kgBB}$ yaitu dengan perbandingan $73,33 \%$ dan $79,97 \%$ dengan perbedaan persentase efek analgetik sebesar 6,64 \%.

\section{SARAN}

1. Perlu dilakukan penelitian lebih lanjut mengenai senyawa yang terkandung didalam ekstrak daun lidah buaya dan ekstrak jahe sebagai zat yang memiliki efek analgetik atau zat yang memiliki manfaat dalam Kesehatan.

2. Perlu dilakukan penelitian yang serupa dengan dosis yang berbeda, bisa yang lebih tinggi maupun lebih rendah dan kontrol positif yang berbeda selain asam mefenamat untuk melihat perbandingan efektivitas yang ditimbulkan dari ekstrak daun lidah buaya dan ekstrak jahe.

3. Perlu dilakukan uji efek analgetik kombinasi ekstrak daun lidah buaya dan ekstrak jahe dengan metode lainnya selain dengan induksi kimia seperti asam asetat..

\section{DAFTAR PUSTAKA}

1. Andarmoyo S. KONSEP \& Proses Keperawatan Nyeri. In: Nyeri. 2013.

2. Bahrudin M. Patofisiologi Nyeri (Pain). Saintika Med. 2018;13(1):7.

3. Scholz J, Finnerup NB, Attal N, Aziz Q, Baron R,
Bennett MI, et al. The IASP classification of chronic pain for ICD-11: Chronic neuropathic pain. Pain. 2019.

4. Tamsuri A. Konsep Dan Penatalaksanaan Nyeri. EGC, Jakarta. 2007.

5. Kozier B, Erb G, Berman A, Snyder SJ. Keperawatan Perioperatif. In: Buku Ajar Fundamental Keperawatan. 2010.

6. Berman A, Snyder S, Levett-Jones T, Dwyer T, Hales M, Harvery $N$, et al. Kozier and Erb's Fundamentals of Nursing. Kozier and Erb's Fundamentals of Nursing. 2012.

7. World Health Organisation (WHO). WHO's pain ladder. World Health Organisation. 2012.

8. Bertha C, Lumban U, Bodhi W, Lolo WA. UJI EFEK ANALGETIKA EKSTRAK ETANOL DAUN LIDAH BUAYA (Aloe vera L.) PADA TIKUS PUTIH JANTAN GALUR WISTAR (Rattus norvegicus). Pharmacon. 2016;5(1):8-14.

9. Muqsith A. Jurnal Aceh Medika Uji Daya Analgetik Jus Daun Lidah Buaya ( Aloe Vera Folium ) Pada Mencit ( Mus Musculus ) Betina. 2017;1(1):11-5.

10.Rsud DI, Kota S. Jurnal Farmasi Lampung JFL. 2019;8(2):67-77.

11.Lahamendu B, Bodhi W, Siampa JP. Uji efek analgetik ekstrak etanol rimpang jahe putih (Zingiber officinale Rosc.var. Amarum) pada tikus putih jantan galur wistar (Rattus norvegicus). Pharmacon. 2019;8(4):180-8.

12.M.Alfian Lutfi. Studi efektivitas serum nanopartikel ekstrak etanolik terpurifikasi batang jatropha multifida. L terhadap penyembuhan luka insisi tikus jantan galur wistar. 2019;11-9.

13.Febriani Y, Riasari H, Winingsih W, Aulifa L, Permatasari A. Potensi Pemanfaatan Ampas Jahe Merah (Zingiber officinale Roscoe ) sebagai Obat Analgetik. Indones J Pharm Sci Technol. 2018;1(1):57-64.

14.Kaunang CE, Bodhi W, Edy HJ. Uji Efek Analgetik Nanopartikel Ekstrak Rimpang Jahe Merah ( Zingiber Officinale Var Rubrum ) Pada Tikus Putih Jantan Galur Wistar ( Rattus norvegicus ) Program Studi Farmasi FMIPA UNSRAT Manado.2020;9(1):186-95. 